\title{
PENGARUH MODEL PEMBELAJARAN KOOPERATIF TIPE STAD BERBANTUAN MEDIA KAHOOT! TERHADAP KEMAMPUAN PEMAHAMAN KONSEP MATEMATIS SISWA SMAN 4 BEKASI
}

\author{
Kezia Margareth Ntjalama ${ }^{1}$, Tri Murdiyanto ${ }^{2}$, Meiliasari ${ }^{3}$ \\ ${ }^{1}$ Pendidikan Matematika, FMIPA, Universitas Negeri Jakarta \\ ${ }^{2}$ Dosen Pendidikan Matematika, FMIPA, Universitas Negeri Jakarta \\ ${ }^{3}$ Dosen Pendidikan Matematika, FMIPA, Universitas Negeri Jakarta \\ keziamn@gmail.com
}

\begin{abstract}
Abstrak
Penelitian eksperimen semu ini bertujuan untuk mengetahui apakah terdapat pengaruh model pembelajaran kooperatif tipe STAD berbantuan media Kahoot! terhadap kemampuan pemahaman konsep matematis siswa SMA Negeri 4 Bekasi pada pokok bahasan vektor di ruang dimensi tiga. Desain penelitian ini adalah posttest only control group design. Populasi target dalam penelitian ini adalah seluruh siswa kelas X MIPA SMA Negeri 4 Bekasi yang tersebar ke dalam 7 kelas. Sampel penelitian ini adalah siswa kelas X MIPA 5 dan X MIPA 6 dengan jumlah sampel sebanyak 80 siswa. Pengambilan sampel dalam penelitian ini menggunakan teknik simple random sampling. Berdasarkan analisis data, pengujian hipotesis menggunakan uji- $t$ diperoleh hasil $t_{\text {hitung }}=2,57$ dan $t_{\text {tabel }}=1,99$. Nilai $t_{\text {hitung }}>t_{\text {tabel }}$ sehingga tolak $H_{0}$, maka rata-rata kemampuan pemahaman konsep matematis siswa yang diajar menggunakan model pembelajaran kooperatif tipe STAD berbantuan media Kahoot! lebih tinggi daripada rata-rata kemampuan pemahaman konsep matematis siswa yang diajar dengan model pembelajaran konvensional. Hal ini berarti bahwa model pembelajaran kooperatif tipe STAD berbantuan media Kahoot! berpengaruh terhadap kemampuan pemahaman konsep matematis siswa dimana berdasarkan perhitungan menggunakan Cohen's Effect Size pengaruh yang diberikan tergolong dalam kriteria large (besar) yaitu sebesar 73\%.
\end{abstract}

Kata kunci: Model Pembelajaran Kooperatif Tipe Student Teams Achievement Division (STAD), Kahoot!, Kemampuan Pemahaman Konsep Matematis

\section{PENDAHULUAN}

Pendidikan memiliki peran yang sangat penting dalam kehidupan berbangsa dan bernegara sehingga melalui pendidikan, akan terbentuk generasi-generasi penerus yang cerdas dan kompeten dalam bidangnya sehingga kualitas sumber daya manusia meningkat dan kondisi bangsa dapat mengalami perubahan yang lebih baik. Artinya, sangatlah penting meningkatkan kualitas pendidikan di Indonesia, sehingga melalui pendidikan yang berkualitas, bangsa Indonesia dapat memiliki individu yang siap menanggapi perubahan zaman dan dapat menjadi negara yang maju.

Matematika merupakan ilmu universal yang mendasari perkembangan teknologi modern, mempunyai peran penting dalam berbagai disiplin dan memajukan daya pikir manusia (Depdiknas, 2006a: 345). Tujuan pembelajaran matematika adalah (1) Memahami konsep matematika, menjelaskan keterkaitan antar konsep, dan mengaplikasikan konsep atau algoritma secara luwes, akurat, efisien, dan tepat dalam pemecahan masalah,

Menggunakan penalaran pada pola dan sifat, melakukan manipulasi matematika dalam membuat generalisasi, menyusun bukti atau menjelaskan gagasan dari pernyataan matematika, (3) Memecahkan masalah yang meliputi kemampuan memahami masalah, merancang teknik matematis, menyelesaikan teknik dan menafsirkan solusi yang diperoleh, (4) Mengkomunikasikan gagasan dengan simbol, tabel, diagram, atau media lain untuk memperjelas keadaan atau masalah, dan (5) Memiliki sikap menghargai kegunaan matematika dalam kehidupan, yaitu memiliki rasa ingin tahu, perhatian, dan minat dalam mempelajari matematika, serta sikap ulet dan percaya diri dalam pemecahan masalah (Depdiknas, 2006b: 346). 
Salah satu tujuan pembelajaran matematika adalah pemahaman konsep. Kemampuan pemahaman konsep adalah kemampuan siswa untuk memahami suatu materi pelajaran dalam hal ini matematika, dengan pembentukannya sendiri dan mampu mengungkapkan kembali dalam bentuk lain yang mudah dimengerti serta mengaplikasikannya (Septriani, 2014: 17). Menurut Duffin dan Simpson (dalam Kesumawati, 2008: 230-231) kemampuan pemahaman konsep adalah kemampuan siswa untuk: a) Menjelaskan konsep, dapat diartikan siswa mampu mengungkapkan kembali apa yang telah dikomunikasikan kepadanya; b) Menggunakan konsep pada berbagai situasi yang berbeda; dan c) Mengembangkan beberapa akibat dari adanya suatu konsep, dapat diartikan bahwa siswa paham terdapat suatu konsep akibatnya siswa mempunyai kemampuan untuk menyelesaikan setiap masalah dengan benar.

Kemampuan pemahaman konsep siswa dinilai berdasarkan indikator kemampuan pemahaman konsep. Peraturan Dirjen Dikdasmen Nomor 506/C/Kep/PP/2004 (Hendriana, 2018: 7) merinci indikator pemahaman konsep matematis adalah siswa mampu:

a. Menyatakan ulang sebuah konsep.

b. Mengklasifikasikan objek menurut tertentu sesuai dengan sifatnya.

c. Memberikan contoh dan bukan contoh dari suatu konsep.

d. Menyajikan konsep dalam berbagai bentuk representasi matematis.

e. Mengembangkan syarat perlu atau syarat cukup dari suatu konsep.

f. Menggunakan dan memanfaatkan serta memilih prosedur atau operasi tertentu.

g. Mengaplikasikan konsep atau algoritma dalam pemecahan masalah.

Memiliki kemampuan pemahaman konsep merupakan hal penting dalam pembelajaran matematika karena matematika mempelajari konsep-konsep yang saling terhubung dan saling berkesinambungan antara materi yang satu dengan yang lainnya (Zevika, 2012: 45). Jika siswa memiliki pemahaman konsep yang baik maka siswa tersebut akan lebih mudah untuk memahami materi-materi selanjutnya yang lebih kompleks. Namun, jika siswa memiliki pemahaman yang salah terhadap suatu konsep akan berakibat pada kesalahan pemahaman terhadap konsep-konsep selanjutnya dan menyebabkan siswa menjadi sulit dalam proses pembelajaran (Prihandoko, 2006: 1). Oleh karena itu, siswa harus aktif dalam mengembangkan kemampuan pemahaman konsep matematisnya.

Namun, pada kenyataannya kemampuan pemahaman konsep matematis siswa masih rendah. Hal ini dapat dilihat berdasarkan perolehan hasil skor PISA 2015 Indonesia yang masih dibawah rata-rata negara-negara OECD khususnya pada soal level 2 yang mengukur kemampuan pemahaman konsep matematis siswa. Indonesia memeroleh skor rata-rata sebesar 448 sedangkan rata-rata negara-negara OECD sebesar 453. Selain itu, hal lain yang menunjukkan bahwa kemampuan pemahaman konsep matematis siswa masih rendah adalah berdasarkan hasil Penilaian Akhir Semester (PAS) I siswa SMA Negeri 4 Bekasi. Salah satu soal yang diujikan dalam PAS tersebut dapat mengukur kemampuan pemahaman konsep matematis siswa seperti yang terlihat pada Gambar 1 .

30. Diketahui $a>1, b>1$, dan $c>1$. Nilai

$b_{\log \sqrt{a}} \cdot c_{\log b^{2}} \cdot a_{\log \sqrt{c}}$ adalah ...

$\begin{array}{ll}\text { A. } & \frac{1}{4} \\ \text { B. } & \frac{1}{2} \\ \text { C. } & 1 \\ \text { D. } & 2 \\ \text { E. } & 3\end{array}$

Gambar 1. Soal Penilaian Akhir Semester I

Namun, hasil jawaban yang diperoleh pada soal tersebut hanya $42,90 \%$ siswa yang menjawab dengan benar sehingga dapat dikatakan bahwa kemampuan pemahaman konsep matematis siswa kelas X MIPA di SMAN 4 Bekasi masih rendah.

Salah satu penyebab rendahnya kemampuan pemahaman konsep matematis siswa adalah berkaitan dengan proses pembelajaran matematika yang dilaksanakan guru di sekolah. Pembelajaran di sekolah saat ini masih di dominasi oleh guru sebagai pemberi informasi utama, guru secara langsung memberikan penjelasan materi dan konsep-konsep serta contoh-contoh yang berkaitan dengan pembelajaran (Annajmi, 
2016: 2). Siswa kurang terlibat aktif dalam mengkonstruksi sendiri pengetahuannya untuk memahami konsep-konsep yang dipelajari. Siswa tidak banyak terlibat dalam mengkonstruksi pengetahuannya, hanya menerima saja informasi yang disampaikan searah dari guru. Seringkali siswa tidak mampu menjawab soal yang berbeda dari contoh yang diberikan guru. Hal ini dikarenakan siswa hanya mendengar penjelasan guru, mencontoh dan mengerjakan latihan mengikuti pola yang diberikan guru, bukan dikarenakan siswa memahami konsepnya (Annajmi, 2016b: 2)

Kemampuan pemahaman konsep matematis penting dikuasai oleh siswa. Oleh karena itu, permasalahan terhadap rendahnya kemampuan pemahaman konsep matematis harus segera diatasi. Solusi untuk masalah tersebut adalah dengan cara menggunakan perangkat pembelajaran yang tepat sehingga dapat meningkatkan pemahaman konsep matematis siswa. Salah satu cara yang diduga dapat meningkatkan kemampuan pemahaman konsep matematis siswa adalah dengan menggunakan model dan media pembelajaran yang inovatif yaitu dengan menggunakan model pembelajaran kooperatif tipe STAD.

Model pembelajaran kooperatif tipe STAD merupakan model pembelajaran kooperatif yang menekankan pada adanya aktivitas dan interaksi diantara siswa untuk saling memotivasi dan saling membantu dalam menguasai materi pelajaran guna mencapai prestasi yang maksimal (Isjoni, 2016: 51). Dalam STAD, siswa dibagi menjadi kelompok heterogen beranggotakan empat orang dengan beragam kemampuan, jenis kelamin, dan sukunya. Siswa-siswa di dalam kelompok harus memastikan bahwa semua anggota kelompok itu bisa menguasai materi yang diberikan oleh guru sehingga skor kelompok mereka meningkat dan mendapatkan penghargaan.

STAD terdiri atas lima komponen utama: presentasi kelas, kelompok, kuis, skor kemajuan individual, rekognisi kelompok. STAD terdiri atas lima komponen utama: presentasi kelas, kelompok, kuis, skor kemajuan individual, rekognisi kelompok
(Slavin, 2005a: 143). Gagasan utama STAD adalah memacu siswa agar saling mendorong dan membantu satu sama lain untuk menguasai keterampilan yang diajarkan guru. Jika siswa menginginkan kelompok memperoleh hadiah, mereka harus membantu teman sekelompok mereka dalam mempelajari pelajaran (Rusman, 2014: 214).

Namun, model pembelajaran saja tidak cukup untuk meningkatkan kemampuan pemahaman konsep matematis siswa. Sebaiknya, pembelajaran ditunjang dengan penggunaan media pembelajaran yang dapat mempermudah siswa dalam memahami konsep. Salah satu media inovatif yang diduga dapat membantu siswa dalam meningkatkan kemampuan pemahaman konsepnya adalah Kahoot!. Kahoot! merupakan website edukatif yang diinisiasi oleh Johan Brand, Jamie Brooker dan Morten Versvik dalam sebuah proyek gabungan dengan Norwegian University of Technology and Science pada Maret 2013. Kahoot adalah sebuah perangkat lunak pendidikan berbasis permainan yang dapat memungkinkan guru untuk menyediakan kuisioner, diskusi, atau ujian secara online. Kahoot dapat dimainkan dalam dua mode yaitu mode klasik dimana pemain vs pemain secara individu dengan memakai perangkat pemain masing-masing dan mode kelompok dimana kelompok vs kelompok dengan menggunakan satu perangkat.

Kahoot! memiliki 4 jenis pilihan yaitu: Quiz, Jumble, Discussion, dan Survey dimana setiap jenis memiliki cara yang bermacammacam unuk dimainkan. Pada jenis Quiz guru mengajukan pertanyaan pilihan ganda dan siswa memilih jawaban yang benar dari pilihan tersebut, Jumble siswa diminta untuk mengurutkan jawaban yang di acak dari pertanyaan yang diajukan, Discussion guru mengajukan pertanyaan untuk memicu adanya perdebatan, dan Survey guru dapat mengumpulkan pendapat siswa. Dalam penelitian ini Kahoot! jenis Quiz yang akan digunakan dalam proses pembelajaran yang menggunakan model pembelajaran kooperatif tipe STAD.

Kahoot! dapat digunakan dalam proses pembelajaran dan menjadikan 
pembelajaran menjadi menarik. Selain itu, Kahoot! dapat digunakan untuk berbagai penilaian dan proyek termasuk penilaian formatif, penilaian diagnostik, proyek penelitian dan presentasi (Dellos, 2015a: 51). Di antara setiap pertanyaan Kahoot! menunjukkan grafik distribusi jawaban siswa, sehingga memungkinkan guru untuk segera menerima umpan balik tentang apakah konsep telah dipahami oleh seluruh siswa di kelas atau diperlukan elaborasi lebih lanjut (Fotaris, 2016: 99).

Berdasarkan uraian di atas, diduga bahwa kemampuan pemahaman konsep matematis siswa yang diajarkan menggunakan model pembelajaran kooperatif tipe STAD berbantuan media Kahoot! lebih tinggi daripada kemampuan pemahaman konsep matematis siswa yang diajarkan menggunakan model pembelajaran konvensional. Oleh karena itu, tujuan penelitian ini adalah untuk mengetahui apakah model pembelajaran kooperatif tipe STAD berbantuan media Kahoot! berpengaruh terhadap kemampuan pemahaman konsep matematis siswa SMA Negeri 4 Bekasi dan jika terdapat pengaruh berapa besar pengaruh yang dihasilkan oleh model pembelajaran kooperatif tipe STAD berbantuan media Kahoot! berpengaruh terhadap kemampuan pemahaman konsep matematis siswa.

\section{METODE PENELITIAN}

Jenis penelitian ini adalah quasi experiment (eksperimen semu). Penelitian ini melibatkan dua kelas, yaitu kelas yang mendapat perlakuan pembelajaran kooperatif tipe STAD berbantuan media Kahoot! dan kelas yang yang memeroleh pembelajaran dengan model pembelajaran konvensional. Variabel bebas dalam penelitian ini adalah model pembelajaran kooperatif tipe STAD berbantuan media Kahoot! dan model pembelajaran konvensional. Variabel terikatnya adalah kemampuan pemahaman konsep matematis siswa. Desain penelitian yang digunakan adalah Posttest Only Control Group Design. Desain dalam penelitian ini dapat digambarkan sebagai berikut:

\section{Tabel 1. Desain Penelitian}

\begin{tabular}{|c|c|c|}
\hline Kelas & Perlakuan & Tes \\
\hline R1 & $\mathrm{X}$ & $\mathrm{Y}$ \\
\hline $\mathrm{R} 2$ & - & $\mathrm{Y}$ \\
\hline
\end{tabular}

Keterangan:

R1 : Kelompok eksperimen

R2 : Kelompok kontrol

$\mathrm{X}$ : Perlakuan yang diberikan yaitu berupa pembelajaran matematika menggunakan model pembelajaran kooperatif tipe STAD berbantuan media Kahoot!

- : Perlakuan yang diberikan yaitu berupa pembelajaran matematika menggunakan model pembelajaran konvensional

$\mathrm{Y} \quad$ : Tes tertulis kemampuan pemahaman konsep matematis siswa

Populasi penelitian adalah siswa kelas $\mathrm{X}$ MIPA SMA Negeri 4 Bekasi pada tahun ajaran 2018/2019. Sebelum melakukan pengambilan sampel, dilakukan uji prasyarat analisis data sebelum perlakuan terlebih dahulu, yaitu uji normalitas, uji homogenitas, dan uji kesamaan rata-rata. Hasil pengujian tersebut menunjukkan bahwa kelas X MIPA 2 hingga X MIPA 6 memiliki populasi yang berdistribusi normal, homogen, dan memiliki kesamaan rata-rata. Selanjutnya dilakukan pengambilan sampel dengan teknik simple random sampling, yaitu pengambilan sampel dari populasi dilakukan secara acak dan pemilihannya mengacu pada kelas. Dari hasil pengambilan sampel, ditetapkan kelas X MIPA 6 sebagai kelas eksperimen dan kelas X MIPA 5 sebagai kelas kontrol.

Instrumen yang digunakan dalam penelitian ini adalah berupa tes kemampuan pemahaman konsep matematis berbentuk tes uraian sebanyak 5 soal pada pokok bahasan yang telah dipelajari pada kelas eksperimen dan kelas kontrol yaitu vektor. Tes pemahaman konsep matematis diberikan sebagai posttest. Posttest diberikan dengan tujuan untuk mengetahui kemampuan pemahaman konsep matematis siswa yang diajar menggunakan model pembelajaran kooperatif tipe STAD berbantuan media Kahoot!. apakah lebih baik dibandingkan dengan siswa yang diajar dengan 
menggunakan model pembelajaran konvensional. Data hasil posttest kemampuan pemahaman konsep matematis kemudian dianalisis dengan menggunakan uji- $t$.

\section{HASIL DAN PEMBAHASAN}

Hasil analisis data tes kemampuan pemahaman konsep matematis siswa pada kelas eksperimen dan kelas kontrol dapat dilihat pada tabel 2 .

Tabel 2. Hasil Deskripsi Data Tes Kemampuan Pemahaman Konsep

\begin{tabular}{|c|c|c|c|c|c|}
\hline Kelas & $\mathbf{N}$ & $\overline{\boldsymbol{x}}$ & $\boldsymbol{S}$ & $\boldsymbol{X}_{\text {maks }}$ & $\boldsymbol{X}_{\text {min }}$ \\
\hline Eksperimen & 40 & 81,88 & 11,02 & 100 & 60 \\
\hline Kontrol & 40 & 75,13 & 12,43 & 100 & 50 \\
\hline
\end{tabular}

Berdasarkan tabel 2, terlihat bahwa ratarata skor kelas eksperimen yaitu 81,88 lebih tinggi dibandingkan dengan rata-rata skor kelas kontrol yaitu 75,13. Dilihat dari simpangan baku, kelas kontrol memeroleh skor yang lebih tinggi dibandingkan kelas eksperimen, artinya kemampuan pemahaman konsep matematis siswa kelas kontrol lebih beragam daripada kemampuan pemahaman konsep matematis siswa kelas eksperimen.

Berdasarkan hasil analisis data, pengujian hipotesis menggunakan uji- $t$ diperoleh hasil $t_{\text {hitung }}=2,57$ dan $t_{\text {tabel }}=$ 1,99. Dapat dilihat bahwa $t_{\text {hitung }}>t_{\text {tabel }}$ sehingga tolak $H_{0}$. Dengan demikian, dapat disimpulkan bahwa setelah diberikan perlakuan, rata-rata kemampuan pemahaman konsep matematis siswa yang diajar menggunakan model pembelajaran kooperatif tipe STAD berbantuan media Kahoot! lebih tinggi dibandingkan dengan rata-rata siswa yang diajar dengan menggunakan model pembelajaran konvensional. Hal ini menunjukkan bahwa terdapat pengaruh yang signifikan antara model pembelajaran kooperatif tipe STAD berbantuan media Kahoot! terhadap kemampuan pemahaman konsep matematis siswa SMA Negeri 4 Bekasi pada materi vektor di ruang dimensi tiga.
Selanjutnya, untuk mengetahui seberapa besar pengaruh signifikan model pembelajaran kooperatif tipe STAD berbantuan media Kahoot! terhadap kemampuan pemahaman konsep matematis siswa. Perhitungan besar pengaruh dilakukan dengan menggunakan rumus Cohen's Effect Size $(d)$. Hasil perhitungan memperoleh nilai $d=0,6$. Berdasarkan tabel Cohen's Effect Size (d) diketahui bahwa besar pengaruh tergolong dalam kriteria large (besar) dengan persentase pengaruh sebesar $73 \%$. Dengan demikian, dapat disimpulkan bahwa terdapat pengaruh yang signifikan antara model pembelajaran kooperatif tipe STAD berbantuan media Kahoot! terhadap kemampuan pemahaman konsep matematis siswa SMA Negeri 4 Bekasi pada materi vektor di ruang dimensi tiga yang tergolong large (besar) yaitu sebesar $73 \%$.

Pelaksanaan pembelajaran dengan menggunakan model pembelajaran kooperatif tipe STAD berbantuan media Kahoot! dalam penelitian ini sudah terlaksana sesuai dengan karakteristik dan tahap-tahap pembelajaran model pembelajaran kooperatif tipe STAD berbantuan media Kahoot!. Model pembelajaran kooperatif tipe STAD berbantuan media Kahoot! dilaksanakan melalui enam tahapan, yaitu penyampaian tujuan dan memotivasi siswa, membagi siswa dalam kelompok heterogen, penyampaian materi, kegiatan belajar dalam kelompok, kuis, dan pemberian penghargaan. Pada penelitian ini, kemampuan pemahaman konsep matematis siswa berkembang karena adanya tahapan-tahapan pada model pembelajaran kooperatif tipe STAD berbantuan media Kahoot! yang melibatkan siswa dalam memahami konsep lebih optimal dan juga menuntut siswa untuk bertanggung jawab dalam memahami materi pelajaran. Tahapan-tahapan tersebut adalah penyampaian materi, kegiatan belajar dalam kelompok, dan kuis.

Tahap penyampaian materi yang dilakukan oleh guru merupakan tahap awal yang membantu siswa dalam mendapatkan konsep mengenai materi yang dipelajari. Hal ini dikarenakan tujuan utama dari tahap ini adalah pemahaman siswa 
terhadap materi. Guru menyampaikan materi pelajaran dibantu dengan presentasi PowerPoint yang dibuat secara ringkas namun tetap menekankan kepada konsep materi vektor di ruang dimensi tiga itu sendiri. Penyampaian materi yang dilakukan oleh guru tidak menjadikan siswa menjadi pasif dalam pembelajaran melainkan siswa secara aktif berinteraksi dengan guru. Guru sering mengadakan tanya jawab dengan siswa untuk mengontrol pemahaman siswa mengenai materi yang sedang dipelajari. Oleh karena itu, dalam tahapan ini kemampuan pemahaman konsep matematis siswa sudah mulai berkembang.

Selanjutnya, tahapan kegiatan belajar dalam kelompok. Kegiatan yang dilakukan siswa ketika belajar dalam kelompok adalah mengerjakan LAS yang diberikan oleh guru dan mendalami materi yang telah disampaikan oleh guru bersama-sama dengan anggota kelompoknya. Pada pertemuan pertama kegiatan belajar mengajar, siswa di kelas eksperimen terlebih dahulu dibagi ke dalam kelompokkelompok heterogen yang beranggotakan $4-5$ siswa. Siswa di kelas eksperimen berjumlah 41 siswa sehingga terbentuk 10 kelompok yang terdiri atas 9 kelompok beranggotakan 4 orang siswa dan 1 kelompok beranggotakan 5 orang siswa.

Kegiatan belajar dalam kelompok membuat siswa dapat saling memotivasi dan saling membantu dalam menguasai materi pelajaran. Siswa dengan kemampuan akademik yang lebih tinggi membantu teman satu kelompoknya yang kesulitan dalam memahami materi, sedangkan siswa yang memiliki kemampuan akademik yang lebih rendah terpacu untuk semangat dalam memahami materi karena setiap anggota dalam kelompok memiliki tanggung jawab untuk menguasai materi yang sedang dipelajari. Hal ini sesuai dengan teori motivasi yang dikemukakan oleh Slavin bahwa untuk meraih tujuan, anggota kelompok harus membantu teman satu kelompoknya guna membuat kelompok mereka berhasil dan mendorong anggota satu kelompoknya untuk melakukan usaha maksimal (Slavin, 2005b: 54). Selain itu, siswa tidak segan-segan bertanya kepada guru jika ada kesulitan dalam memahami materi dan mengerjakan LAS. Guru akan memberikan pertanyaan stimulus yang dapat mengarahkan siswa dalam menyelesaikan soal tersebut secara mandiri. Oleh karena itu, dapat dikatakan bahwa kegiatan belajar dalam kelompok inilah yang merupakan kunci utama siswa dalam mengembangkan kemampuan pemahaman konsep matematisnya. Hal ini diperkuat dengan teori Slavin yang menyatakan bahwa dengan berdiskusi mengenai materi maka pemahaman dengan kualitas yang lebih tinggi akan muncul (Slavin, 2005c: 38).

Tahapan terakhir yang dapat mengembangkan kemampuan pemahaman konsep matematis siswa adalah kuis. Kuis dilaksanakan dengan tujuan untuk mengetahui sejauh mana pemahaman siswa terhadap materi yang dipelajari. Kuis diberikan secara individu dengan menggunakan media Kahoot! yang diakses melalui smartphone masing-masing siswa pada situs https://kahoot.com/. Sebelumnya, guru akan menjelaskan sistem kuis pada Kahoot! dan meminta siswa untuk menghubungkan koneksi internet smartphonenya dengan jaringan $\mathrm{Wi}-\mathrm{Fi}$ yang tersedia di sekolah.

Penggunaan media Kahoot! merupakan salah satu kelebihan yang terdapat dalam penelitian ini. Ada beberapa hal yang dapat dilihat dalam penggunaan media Kahoot! selama kuis berlangsung yaitu: Pertama, siswa sangat antusias, tertarik, dan semangat dalam mengerjakan setiap soal kuis yang ada di Kahoot! terlebih lagi ketika mereka mengetahui apakah jawaban mereka benar atau salah dan posisi peringkat mereka dalam satu kelas. Hal ini sesuai dengan fungsi media yaitu, membuat pembelajaran menjadi lebih menarik dan merangsang siswa untuk fokus. Selain itu, hal ini juga sejalan dengan penelitian sebelumnya yang menyatakan bahwa penggunaan media Kahoot! mampu mengurangi kebosanan dan kejenuhan siswa serta meningkatkan aktivitas dan partisipasi aktif siswa dalam pembelajaran (Nugraha, 2018: 153). Kedua, siswa tidak merasa tertekan ketika mengerjakan soal kuis melalui media Kahoot!. Hal ini sesuai dengan pernyataan penelitian sebelumnya yang menyatakan bahwa dengan Kahoot!, siswa mampu menunjukkan pengetahuan, pemahaman, dan kemampuan 
yang mereka miliki tanpa adanya tekanan (Dellos, 2015b: 51). Ketiga, media Kahoot! dapat memudahkan guru untuk segera menerima umpan balik tentang apakah konsep telah dipahami oleh siswa melalui papan skor yang terdapat di layar proyeksi, dalam hal lain, media Kahoot! juga memudahkan guru dalam menghitung skor kuis yang diperoleh masingmasing siswa sehingga tidak membutuhkan waktu yang relatif lama karena seluruh skor kuis yang diperoleh siswa akan dapat langsung diunduh oleh guru. Hal ini sesuai dengan fungsi penggunaan media dalam pembelajaran yaitu, waktu pelaksanaan pembelajaran dapat diperpendek (Sundayana, 2014: 8).

Berdasarkan penjelasan yang telah diuraikan, diketahui pembelajaran matematika dengan menggunakan model pembelajaran kooperatif tipe STAD berbantuan media Kahoot! memberikan pengaruh yang positif terhadap kemampuan pemahaman konsep matematis siswa. Siswa menjadi terlibat aktif dalam mengkonstruksi pengetahuannya untuk memahami konsepkonsep yang dipelajari. Dengan demikian, berdasarkan penelitian yang dilakukan, model pembelajaran kooperatif tipe STAD berbantuan media Kahoot! dapat diterapkan sebagai salah satu alternatif dalam pembelajaran matematika untuk mengembangkan kemampuan pemahaman konsep matematis siswa.

\section{KESIMPULAN}

Terdapat perbedaan kemampuan pemahaman konsep matematis antara siswa yang diajar dengan menggunakan model pembelajaran kooperatif tipe STAD berbantuan media Kahoot! dengan siswa yang diajar dengan menggunakan model pembelajaran konvensional. Hal ini ditinjau berdasarkan hasil perhitungan uji- $t$ yang diperoleh $t_{\text {hitung }}=2,57$ dan $t_{\text {tabel }}=1,99$ pada taraf signifikansi $\alpha=0,05$ karena $t_{\text {hitung }}>t_{\text {tabel }}$ maka tolak $\mathrm{H}_{0}$. Ini berarti rata-rata kemampuan pemahaman konsep matematis siswa yang diajar dengan menggunakan model pembelajaran kooperatif tipe STAD berbantuan media Kahoot! lebih tinggi daripada rata-rata siswa yang diajar dengan menggunakan model pembelajaran konvensional. Dengan demikian, dapat disimpulkan bahwa model pembelajaran kooperatif tipe STAD berbantuan media Kahoot! berpengaruh terhadap kemampuan pemahaman konsep matematis siswa. Pengaruh model pembelajaran kooperatif tipe STAD berbantuan media Kahoot! terhadap kemampuan pemahaman konsep matematis siswa tergolong besar dengan persentase 73\%. Hal ini ditinjau berdasarkan hasil perhitungan Cohen's Effect Size (d).

\section{UCAPAN TERIMA KASIH}

Penulis ingin mengucapkan terima kasih kepada pihak-pihak yang sudah dengan sabar membantu dan membimbing penulis dalam penulisan dan penelitian jurnal ini. Terima kasih untuk Pak Drs. Tri Murdiyanto, M.Si selaku dosen pembimbing I, Ibu Dr. Meiliasari, S.Pd., M.Sc selaku dosen pembimbing II, Ibu Dwi Sartika Sari selaku guru matematika di SMAN 4 Bekasi, Orang tua dan adik-adik tercinta, dan sahabat-sahabat penulis yang tidak dapat disebutkan satu persatu namanya. Kiranya Tuhan Yang Maha Esa akan membalas kebaikan kalian.

\section{DAFTAR PUSTAKA}

Annajmi. (2016). "Peningkatan Kemampuan Pemahaman Konsep Matematik Siswa SMP Melalui Metode Penemuan Terbimbing Berbantuan Software Geogebra."Journal of Mathematics Education and Science, 2 (1), 2.

Dellos, Ryan. (2015). "Kahoot! A Digital Game Resource for Learning", International Journal of Instructional Technology and Distance Learning, 12 (4), 51.

Depdiknas. (2006). Permendiknas Nomor 22 Tahun 2006 Tentang Standar Isi Untuk Satuan Pendidikan Dasar dan Menengah. Jakarta: Depdiknas.

Fotaris, Panagiotis, Theodoros Mastoras, Richard Leinfellner, dan Yasmine Rosunally. 2016. "Climbing Up the Leaderboard: An Empirical Study of Applying Gamification Techniques to a Computer Programming Class." Electronic Journal of E-Learning, 12 (2), 99. 
Hendriana, Heris, Euis Eti Rohaeti, dan Utari Sumarmo. 2018. Hard Skills dan Soft Skills Matematik Siswa. Bandung: PT Refika Aditama.

Isjoni. (2016). Cooperative Learning Mengembangkan Kemampuan Belajar Berkelompok. Bandung: Alfabeta.

Kesumawati, Nila. 2008. "Pemahaman Konsep Matematik dalam Pembelajaran Matematika." Seminar Nasional Matematika dan Pendidikan Matematika, 229-235.

Nugraha, Hendra. (2018). "Meningkatkan Pemahaman Matematika Siswa SMP Negeri 1 Pageden Kelas VIII dengan Gamification Kahoot. UNINUS Journal Published, 2 (2), 153.

Prihandoko, Antonius Cahya. (2006). Memahami Konsep Matematika Secara Benar dan Menyajikannya Dengan Menarik. Jakarta: Departemen pendidikan Nasional.
Rusman. (2014). Model-model Pembelajaran: Mengembangkan Profesionalisme Guru. Jakarta: Rajawali Press.

Septriani, Nicke, Irwan, dan Meira. (2014). "Pengaruh Penerapan Pendekatan Scaffolding Terhadap Kemampuan Pemahaman Konsep Matematika Siswa". Jurnal Pendidikan Matematika, 3 (3), 17.

Slavin, Robert. (2005). Cooperative Learning Teori, Riset dan Praktik, terj. Narulita Yusron. Bandung: Nusa Media. Sundayana, Rostina. (2014). Media dan Alat Peraga dalam Pembelajaran Matematik. Bandung: Alfabeta.

Zevika, Mona, Yarman, dan Yerizon. (2012). Meningkatkan Kemampuan Pemahaman Konsep Siswa Kelas VII SMP Negeri 2 Padang Panjang Melalui Pembelajaran Kooperatif Tipe Think Pair Share Disertai Peta Pikiran. Jurnal Pendidikan Matematika, 1 (1), 45. 